\title{
English Language Proficiency and Academic Performance of Philippine Science High School Students
}

\author{
Robelle Millie Ann B. Racca and Ronald Candy S. Lasaten
}

\begin{abstract}
Using the descriptive-correlational research design, this study aimed to determine the relationship between the English language proficiency and academic performance in Science, Mathematics and English of the 216 Grade 8 students of Philippine Science High School in Northern Luzon - Ilocos Region Campus, Cordillera Autonomous Region and Cagayan Valley Campus. Frequency distribution and Pearson's $r$ correlation were the statistical tools used to treat the data. Findings reveal that majority of the Grade 8 students of the Philippine Science High School in Northern Luzon have English language proficiency belonging to the satisfactory level. Also, majority of the students have academic performance in Science and Mathematics belonging to the very good level while good level in English. Results further reveal that there is a significant relationship between the students' English language proficiency and their academic performance in each of the subjects.
\end{abstract}

Index Terms-Academic performance, cognitive academic language proficiency (CALP), English language proficiency, Philippine Science High School.

\section{INTRODUCTION}

In a report published by [1] called Business English Index (BEI), Philippines was tagged as the world's best country in business English proficiency, in not just one but two consecutive years. Based on the BEI Report in 2012, only the Philippines attained a score above 7.0, putting the country within range of a high proficiency that indicates an ability to lead business discussions and perform complex tasks. Moreover, in 2013 BEI report, the Philippines earned 7.95 score, an improved BEI score over the prior year. This maybe the reason why the Philippines has taken over India as a hub for call centers in Asia.

However, various studies reveal that the quality of education in the Philippines is continuously declining. This notion is based on the results of achievement tests and board examinations. Not only the elementary and secondary graduates are affected but also the college graduates. The Professional Regulatory Commission (PRC) reports that passers of board examinations in all fields of endeavor continue to go down. One of the important causes for this phenomenon is the low academic performance in the elementary and secondary levels. This academic performance of the students can be attributed to their proficiency in the

Manuscript received February 20, 2016; revised June 12, 2016.

R. M. B. Racca is with the Philippine Science High School-Ilocos Region Campus, San Ildefonso, Ilocos Sur, Philippines (e-mail: robelleracca_23@yahoo.com.ph).

R. C. S. Lasaten is with the Mariano Marcos State University College of Teacher Education (MMSU-CTE), Laoag City, Philippines (e-mail: ronaldcandylasaten@yahoo.com.ph).
English language.

Educators agree that proficiency in the English language is the basis for success in academic pursuits. Reading, writing, and working with numbers are tasks that are based on language skills [1], [2] describes this as the interplay between everyday language skills and more advanced communication skills.

Indeed, language proficiency is a key to academic performance. A person who does not know English, for instance, may not have access to the world's known scientific and technological discoveries that are predominantly written in English [3]. This means that students need to be proficient in English for a better grasp of knowledge in Technology, Science, and Mathematics.

As [4] claim, language proficiency in English is significantly related to academic performance. Academic subjects like Science, Mathematics and English often requires the use of language functions. The language functions play a significant role in critical and analytical thinking required in science and mathematics subjects. The more language functions with which students are adept, the more effective their thinking can be. Thus, the more the students are proficient with the English language, the more they are likely to perform well in their academic subjects.

Relative to the said claim, the Department of Education (DepEd) asserts that students' proficiency in Science and Mathematics has a relationship with their language proficiency in English. Majority of the students had not really mastered the different learning areas in Mathematics. From the performance of Grade VI pupils, it was reflected that their skills in problem solving was only 53\%; analysis, 56\%; and computation was $62 \%$. These skills all require proficiency in English. Likewise, from the results yielded, Science noticeably tailed at fifth rank with only $56.87 \%$ percentile rank. It was noted that the questions given required comprehension and analytical skills of the learners. Again, English has something to do with the skills of the learners [5]. Undeniably, in many a lesson in Sciences and Mathematics, English is very vital as a tool in comprehension, analysis, evaluation, and interpretation of results.

Multifarious interventions have been made to address such claim and assertion. However, still a lot of students struggle in Science, Mathematics and English. This phenomenon is also true to Philippine Science High School (PSHS) students who are marked with excellence in Science, Mathematics and Technology.

In the study of [6], they contend that Science, in all areas, is not being mastered by the students. These range from interpreting and analyzing scientific data, to explaining and proving scientific theories or laws, to being able to solve 
scientific problems or to refute or confirm a theory. In Mathematics, the students are poor in solving problems or even in interpreting and analyzing data. They are also weak in terms of manipulating numbers and equations. Likewise, they are weak in thinking conceptually and spatially. Indeed, their analytical, critical and problem-solving skills are poor.

The study of [6] concludes that the students' weaknesses in Science and Mathematics subjects are attributed to the students' difficulty in English. As stated in his findings, the students' difficulty in English included difficulties in making inferences and interpretations of information, deducing meaning, drawing conclusions, and summarizing ideas. All these boil down to problem on comprehension, leading the students not to understand what they are reading. They are not developing proficiency in the language. They have difficulty in expressing their ideas in spoken and written form. Obviously, the skills in English are pre-requisites in learning concepts in Science and Mathematics.

Based on the experiences and observations of their English teachers, the students normally refuse or react negatively when given literary pieces and novels for home reading reports and compositions and analyses for submission. This is true to most, if not all, experiences of the language teachers in the said institution. Same observations are also perceived by the Science and Mathematics teachers. They say that the students have difficulty in articulating their ideas, analyzing problem sets and applying theory in given situations. Generally, the students complain that they could hardly understand a language that is not native to them even they try all the means to learn it. To them, even how competent their teachers are in the language, still they could hardly attain proficiency in the language.

These observations relative to English language proficiency and academic performance prompted the researchers to conduct this study. Particularly, this research assesses the relevance of language proficiency to the academic performance of the students in Science, Mathematics and English.

\section{OBJECTIVES OF THE STUDY}

This research primarily aimed to determine the relationship between the English language proficiency and the academic performance of the Grade 8 students of Philippine Science High School in Northern Luzon.

Likewise, the study endeavored to determine and describe the English language proficiency level and academic performance in Science, Mathematics and English of the Grade 8 students of Philippine Science High School.

\section{SignificANCE OF THE STUDY}

The findings of this study could provide a database that can be used as a tangible reference for more meaningful educational services. Results could be useful in the solution of problems related to English language teaching and learning. Definitely, students, teachers, administrators, parents and other research enthusiasts could benefit from this study.

With the result of this study, the students of PSHS-IRC could find essential feedback and information as regards their language learning which could provide guidance and direction on better English language skills development and for a more improved language performance. Moreover, they could also be directed to focus in any of the language proficiency skills identified as weak among them.

Moreover, the results could also guide the teachers in English relative to information on the level of the students' language proficiency and academic performance. They can use the essential information to improve their teaching practices. With the results, they could then device approaches and strategies on how to integrate learning content with the students' current deficiencies. Consequently, emphasis on the improvement of the English program will be looked into.

Furthermore, the administration could use the results of the study as a reference in formulating school policies and programs. Through the results, they can propose and initiate in-service trainings and seminars for the teachers. Gradually, the English program content can be improved based on the needs of the students. Significantly, the results can shed light in evaluating the Sciences and Mathematics programs of the school.

This study could also be beneficial to parents for the upcoming grade levels since results will guide them in choosing the opportunities and interventions that should be provided to their children so as to enhance their language proficiency and academic performance.

Lastly, the result of the study could provide meaningful data useful for other research enthusiasts. Hopefully, more replicate studies along this line of concern can be done to further ascertain relationship of language proficiency and academic performance.

\section{SCOPE AND DELIMITATIONS OF THE STUDY}

This study primarily focused on the relationship between the English language proficiency and academic performance in Science, Mathematics and English of the Grade 8 students of the Philippine Science High School in Ilocos Region, Cordillera Autonomous Region, and Cagayan Valley Region.

The choice of the locale is prompted by the fact that they are the forerunners in Science and Technology, a name in the academe as flagship of quality education in the North. With this, it is presumed that the students belonging to said school could be the best representative of the desired type of students for the study.

The English language proficiency level of the students was delimited to the result of the National Competitive Examination along Verbal Aptitude, which tests the students' skills in grammar, vocabulary and reading comprehension. Meanwhile, the level of academic performance was delimited to the students' grade point averages (GPAs) in Science, Mathematics and English from their report cards in Grade 7. Only the students' academic performance in the three subject areas was included since these subjects use English as a medium of instruction.

\section{THEORETICAL AND CONCEPTUAL FRAMEWORK}

This study was anchored on Cognitive Academic Language 
Proficiency (CALP) which delineates the connection between students' cognitive and linguistic processes to their academic performance. There are two levels of language proficiency. These are the basic interpersonal communicative skills (BICS) and the CALP.

The BICS concept signifies the students' language informal conversation. These are used by students when they talk to their parents, siblings, parents and peers in real settings and situations, that is; situations in which the context offers cues that make understanding not totally dependent on verbal interaction alone. [2] refers to this everyday conversational ability as context embedded or contextualized. It has been found by [7] that in context embedded or contextualized communication, the conversation is natural, and deals with ordinary matters requiring speakers to react and respond to each other.

Meanwhile, according to [2] and [7], CALP is the type of language proficiency needed in the academic settings. Classroom activities like reading, writing, participating in formal conversations and taking exams are some of the tasks that require CALP. Thus, students who have not yet developed their CALP may encounter difficulties in learning science, mathematics and other academic subjects.

The CALP concept is related to literacy skills in the first or second language. Both higher levels of language and cognitive processes are required in order to develop the language proficiency needed for achievement in school. [8], [9] have conceptualized the relationship of language proficiency and academic achievement by using an iceberg representation. In this representation, BICS or skills that depend on the surface features of language and lower levels of cognitive processes are represented above the waterline while the CALP or skills related to the meaning of language and higher level of cognitive processes are represented below the waterline.

All children develop BICS and learn to communicate in their native or first language. On the other hand, CALP reflects a combination of language proficiency and cognitive processes that determine a student's success in school [10]. CALP enables the student to learn in a context, which relies heavily on oral explanation of abstract ideas. This is often the context in which high school science is taught, with unfamiliar events or topics being described to students with little or no opportunity to negotiate shared meaning [6].

According to [7-[9], students who have not yet developed their cognitive academic language proficiency (CALP) will surely meet difficulties and problems in several contexts and situations.

The theory on CALP, therefore, provided the researcher a reason to study and investigate the relationship of English language proficiency and academic performance of the Philippine Science High School students.

With the tenets of CALP, the researchers were inspired to conduct this present study.

Based on Fig. 1, the researchers conceptualize that the English language proficiency of the Grade 8 students of Philippine Science High School affects their academic performance in Science, Mathematics and English. This study believes that if the students have high English language proficiency, they are more likely to perform well in their academics, particularly in the said subjects.

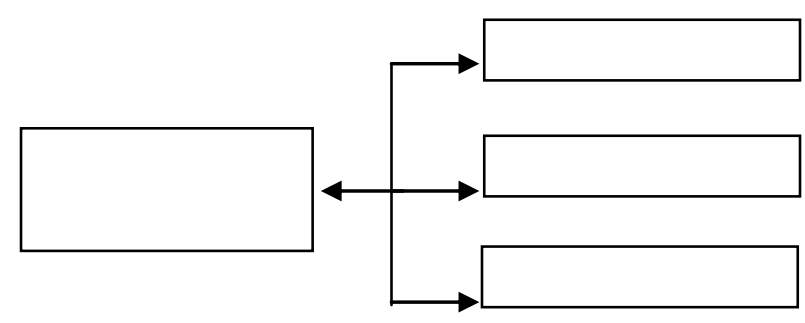

Fig. 1. Research paradigm.

\section{Methodology}

This study used the descriptive-correlational design since its aim was to describe students' English language proficiency and their academic performance levels. Further, the study aimed to correlate the two to determine their relationship.

This study was conducted in the three campuses of Philippine Science High School in Northern Luzon situated in Ilocos Region, Cordillera Autonomous Region and Cagayan Valley. The schools are three of the thirteen campuses of the Philippine Science High School System, a specialized public high school in the Philippines, manned by the Department of Science and Technology (DOST).

Among the 270 Grade 8 students enrolled in the identified three campuses of Philippine Science High School, 80 \% or 216 were selected as samples employing the purposive random sampling technique. This number was considered adequate to represent the whole population.

The data on the students' English language proficiency were based on the result of the NCE Test along Verbal Aptitude. The data were provided by the Admission Committee of the school system. Meanwhile, the data on the students' academic performance in Science, Mathematics and English were taken from the students report cards in Grade 7. These were provided by the school registrar of each campus.

Frequency distribution using range of scores was used in the students' scores in the NCE along Verbal Aptitude while frequency distribution using grade point system was used on the students' academic performance in Science, Mathematics and English. Meanwhile, Pearson's $r$ correlation was used to determine the relationship between the English language proficiency and academic performance of the students. In the tests of hypotheses, the level of significance was set at the .05 probability level.

\section{RESULTS AND DISCUSSIONS}

\section{A. Students' Level of English Language Proficiency}

One of the concerns of the study is to determine and describe the level of English language proficiency of the Grade 8 students of Philippine Science High School based on their scores in the NCE along Verbal Aptitude which tested the students' skills in grammar, vocabulary and reading comprehension. The data showing the level are presented in Table I.

It can be deduced from the table that majority (148 or $68.52 \%$ ) of the students gained a satisfactory level of their 
language proficiency test in NCE with scores ranging from 25 to 36 . Meanwhile, 39 students $(18.05 \%)$ obtained a fair level while 29 students attained a very satisfactory level. Notably, none of the students belongs to the excellent or the poor level. Importantly, the mean of the students' language proficiency is 30.05, with standard deviation of 5.66 .

TABLE I: DistribUtion OF THE STUDENTS’ LEVEL OF ENGLISH LANGUAGE PROFICIENCY

\begin{tabular}{cccc}
\hline \hline $\begin{array}{c}\text { Range of Scores } \\
\text { (Verbal Aptitude } \\
\text { in NCE) }\end{array}$ & $\begin{array}{c}\text { Level of English } \\
\text { Language Proficiency }\end{array}$ & $f$ & $\%$ \\
\hline $49-60$ & Excellent & 0 & 0.00 \\
$37-48$ & Very satisfactory & 29 & 13.43 \\
$25-36$ & Satisfactory & 148 & 68.52 \\
$13-24$ & Fair & 39 & 18.05 \\
$0-12$ & Poor & 0 & 0.00 \\
Mean =30.05 (Satisfactory) & Standard Deviation $=5.66$ \\
\hline \hline
\end{tabular}

The result indicates that the students have average English language proficiency level. This further implies that the students have typical skills in grammar, vocabulary and reading comprehension. Thus, the students have to be exposed to more reading and writing activities to further enhance their English language proficiency level.

\section{B. Students' Level of Academic Performance}

Another concern of the study is to determine the academic performance of the students in Science, Mathematics and English based on the students' grade point averages (GPAs) in their report cards in Grade 7. Apparently, these subjects use English as the medium of instruction.

TABLE II: Distribution OF THE STUdents’ ACADEMIC PERFORMANCE IN

\begin{tabular}{|c|c|c|c|}
\hline \multicolumn{4}{|c|}{ SCIENCE } \\
\hline Grades & Description & $f$ & $\%$ \\
\hline 1.00 & Excellent & 0 & 0.00 \\
\hline 1.25 & Highly Outstanding & 2 & .93 \\
\hline 1.50 & Outstanding & 29 & 13.43 \\
\hline 1.75 & Very Good & 77 & 35.65 \\
\hline 2.00 & Good & 69 & 31.94 \\
\hline 2.25 & Very Satisfactory & 26 & 12.04 \\
\hline 2.50 & Satisfactory & 10 & 4.63 \\
\hline 2.75 & Fair & 3 & 1.38 \\
\hline 3.00 & Poor & 0 & 0.00 \\
\hline & Total & 216 & 100.00 \\
\hline Mean & $1.90($ Very Good $)$ & \multicolumn{2}{|c|}{ Standard Deviation $=.28$} \\
\hline
\end{tabular}

Table II shows the academic performance of the students in Science. It reveals that $77(35.65 \%)$ of the students belong to the very good level, 69 (31.94\%) to good level, 29 (13.43\%) to the outstanding level while $26(12.04 \%)$ to the very satisfactory level. Notably, two students have a highly outstanding level and three $(1.38 \%)$ belong to fair level. No one falls under the excellent and poor levels. Further, the mean of the students' GPA in Science is 1.90 , with standard deviation of 0.28 .

Table III shows the students' academic performance in Mathematics. Based on the table, 56 (25.93\%) of the students belong to the very good level and 43 (19.91\%) of them belong to the outstanding level. On the other hand, 35 (16.20\%) are within the good level and $31(14.35 \%)$ are under the very satisfactory level. Meanwhile, $21(9.72 \%)$ students belong to the satisfactory level, 17 (7.87\%) to the highly outstanding level and one $(0.46 \%)$ to the poor level. The mean of the students GPA in Mathematics is 1.83 , with standard deviation of 0.41 .

TABLE III: Distribution OF THE STUdENTS' ACADEMIC PERFORMANCE IN MATHEMATICS

\begin{tabular}{|c|c|c|c|}
\hline Grades & Description & $f$ & $\%$ \\
\hline 1.00 & Excellent & 10 & 4.63 \\
\hline 1.25 & Highly Outstanding & 17 & 7.87 \\
\hline 1.50 & Outstanding & 43 & 19.91 \\
\hline 1.75 & Very Good & 56 & 25.93 \\
\hline 2.00 & Good & 35 & 16.20 \\
\hline 2.25 & Very Satisfactory & 31 & 14.35 \\
\hline 2.50 & Satisfactory & 21 & 9.72 \\
\hline 2.75 & Fair & 2 & 0.93 \\
\hline \multirow[t]{2}{*}{3.00} & Poor & 1 & 0.46 \\
\hline & Total & 216 & 100.00 \\
\hline \multicolumn{2}{|c|}{ Mean $=1.83($ Very Good $)$} & \multicolumn{2}{|c|}{ Standard Deviation $=0.41$} \\
\hline
\end{tabular}

TABLE IV: Distribution OF THE STUdENTS’ ACADEMIC PERFORMANCE IN

\begin{tabular}{|c|c|c|c|}
\hline \multicolumn{4}{|c|}{ ENGLISH } \\
\hline Grades & Description & $f$ & $\%$ \\
\hline 1.00 & Excellent & 0 & 0.00 \\
\hline 1.25 & Highly Outstanding & 3 & 1.38 \\
\hline 1.50 & Outstanding & 38 & 17.60 \\
\hline 1.75 & Very Good & 50 & 23.15 \\
\hline 2.00 & Good & 63 & 29.17 \\
\hline 2.25 & Very Satisfactory & 48 & 22.22 \\
\hline 2.50 & Satisfactory & 11 & 5.10 \\
\hline 2.75 & Fair & 3 & 1.38 \\
\hline 3.00 & Poor & 0 & 0.00 \\
\hline & Total & 216 & 100.00 \\
\hline $\mathrm{Me}$ & $n=1.94($ Good $)$ & Standa & ation $=.31$ \\
\hline
\end{tabular}

Meanwhile, Table IV indicates the students' academic performance in English. It can gleaned from the table that 63 $(29.17 \%)$ students are within the good level, 50 (23.15\%) to the very good level, and $48(22.22 \%)$ to the very satisfactory level. Evidently, 38 (17.60\%) fall under the outstanding level, $11(5.10 \%)$ to the satisfactory level and three $(1.38 \%)$ each to the highly outstanding and fair level. The mean of the students' GPA in English is 1.94, with a standard deviation of 0.31 .

\section{Relationship of Students' English Language Proficiency and Academic Performance}

TABLE V: COEFFICIENTS OF CORRELATION BETWEEN THE STUDENTS' ENGlish Language ProficIENCY AND TheIR ACADEMIC PERFORMANCE IN EACH OF THE SUBJECTS AND THEIR GENERAL WEIGHTED AVERAGE

\begin{tabular}{|c|c|c|}
\hline Variables & $\begin{array}{c}\text { Correlation } \\
\text { Coefficients }(r)\end{array}$ & Prob \\
\hline Science & -.20 & $\begin{array}{c}.004^{*} \\
*\end{array}$ \\
\hline Mathematics & -.35 & $\begin{array}{c}.000 * \\
*\end{array}$ \\
\hline English & -.35 & $\begin{array}{c}.000^{*} \\
*\end{array}$ \\
\hline General Weighted Average (GWA) & -.11 & $0.03 *$ \\
\hline
\end{tabular}

The study determined if the students' English language proficiency and their academic performance in Science, Mathematics and English have significant relationship. The coefficients of correlation are presented in Table V. 
It can be noted from the table that the students' academic performance in Science $(r=-.20)$ is significantly related to their English language proficiency, which is significant at the .01 level of significance. The negative correlation coefficient implies that as the level of English language proficiency of the students gets high, their grade indicator gets low. Thus, this indicates that the students with high English language proficiency tend to perform, as well, in Science.

Further, it is evident from the results that the students' language proficiency and their academic performance in Mathematics $(r=-.35)$ and English $(r=-.35)$ are significant at the .01 level of significance. The negative correlation coefficient implies that as the level of English language proficiency of the students gets high, their grade indicator gets low. Thus, this indicates that the students with high English language proficiency tend to perform, as well, in Mathematics and English.

Moreover, it can be noted from the table that the general weighted average (GWA) ( $r=-.11)$ is significantly related to their language proficiency which is significant at the .05 level of significance.

The figures show that the relationship between the two variables is indeed significant. In other words, the more language proficient the students are, the better they perform in their Science, Mathematics and English subjects. Further, the students who score high in English language proficiency test have also the tendency to achieve high GPAs.

Thus, the teachers of English, Science and Mathematics at the Philippine Science High School System should be proficient in the English language. The effective use of language in class by the teachers may facilitate the learning of science and math concepts among their students.

The finding of the study is in consonance to the result of the study of [11] which aimed to investigate whether there is a significant relationship between the Iranian college students' language proficiency and their academic performance. Based on the findings, the study found out that a significant relationship between language proficiency and academic performance exists.

The result of the study further corroborates to the results of the study of [4] and [12], which aimed at finding the relationship between academic achievement and language proficiency. Results of their studies showed that there is a significant relationship between English language proficiency and academic achievement.

\section{CONCLUSIONS}

Based on the findings, the study concludes that majority of the Grade 8 students of the Philippine Science High School in Northern Luzon have English language proficiency belonging to the satisfactory level.

Further, the study concludes that the students' academic performance in Science and Mathematics fall under the very good level while good level in English.

Likewise, the study concludes that there is a significant relationship that exists between the students' English language proficiency and their academic performance in Science, Mathematics and English. The higher the English language proficiency levels of the students are the higher their academic performance levels in Science, Mathematics and English.

Thus, the study further concludes that students' English language proficiency could be a predictor in the students' academic performance in Science, Mathematics and English since the medium of instruction used in the teaching of the said subjects is English. Thus, English language program in school should be prioritized.

\section{RECOMMENDATIONS}

In the light of the findings and conclusions, several recommendations are offered to English, Science and Mathematics teachers, students, school administrators, curriculum designers and developers, and other research enthusiasts.

The English teachers of Philippine Science High School should continuously update themselves with new approaches, methods, strategies and techniques in teaching the English subject. This can be done by attending seminars, trainings and workshops related to language and literature teaching. Through this, they can bring out innovations in their teaching and that the proficiency of the students in the English language will be heightened.

The Science and Mathematics teachers of Philippine Science High School should support the English Program of the school. They should promote the use of English language in their classes. Also, they should serve as model to their students in the use of the language. They should not just only teach their students concepts; they should incorporate real life tasks that require the students to use the English language while learning the concepts in Science and Mathematics.

The Grade 8 students of Philippine Science High School should realize the importance of English language in learning Science and Mathematics concepts. They must understand the English language as a system and of the role of its components so as to understand its demands on academic tasks and eventually gain skills to address the role of academic language in their learning.

The school administrators of Philippine Science High School System should have concrete plans to develop and monitor their students' English language proficiency throughout their stay in the institution. Also, they should establish bases and standards for allocating resources that contribute to the students' English language proficiency. Further, they should provide professional development assistance for the faculty to equip them relevant approaches, methods, strategies and techniques in English language teaching.

The curriculum designers and developers of the Philippine Science High School System should revisit the existing curriculum programs of the system, particularly English, Science and Mathematics by taking into consideration the result of the study.

Lastly, other research enthusiasts are encouraged to conduct a similar study on a wider scope to validate the results and findings of the present study. Likewise, they are encouraged to investigate other factors that may contribute to 
students' English language proficiency and academic performance such as learning styles, teaching strategies, technologies used in teaching and learning, exposure to English language, as well as other environmental and contextual variables.

\section{REFERENCES}

[1] Global English Corporation, "Philippines: World's best country in Business English," Business English Index (BEI), vol. 23, no. 4. pp 35-40, September 2014.

[2] J. Cummins, Language Proficiency, Bilingualism and Academic Achievement, White Plains, NY: Longman, 1992, pp. 58-70.

[3] D. Fakeye and Y. Ogunsiji, "English language proficiency as a predictor of academic achievement among ELF students in Nigeria," Journal of Science Research, vol. 37, pp. 490-495, March 2009.

[4] J. K. Aina, A. G. Ogundele, and S. S. Olanipekun, "Students' proficiency in English language relationship with academic performance in science and technical education," American Journal of Educational Research, vol. 9, pp. 355-358, September 2013.

[5] National Statistics Coordination Board, "Quality of basic education remains poor but improving," Eastern Visayas Tops, vol. 12, no. 3, July 2006.

[6] M. M. Javier, "Language proficiency and mental ability as related to critical; Thinking and academic achievement of secondary students: A casual modeling study," M.S. thesis, Philippine Normal University, Manila, 2001.

[7] J. W. Rosenthal, Teaching Science to Language Minority Students, England: Multilingual Matters Ltd., 1996, pp. 329-340.

[8] J. Cummins, Interdependence and Bicultural Ambivalence: Regarding the Pedagogical Rationale for Bilingual Education, Rosslyn, VA: National Clearinghouse for Bilingual Education, 1982, pp. 281-290.

[9] J. M. O'Malley and A. Chamot, Strategies Used by Second Language Learner, Cambridge: Cambridge University Press, 1990, pp. 179-188.

[10] J. Cummins, Language Development and Academic Learning, Clevedon, England: Multilingual Matters, Ltd., 1991, pp. 161-175.

[11] R. Sahragard, A. Baharloo, and S. M. A. Soozandehfar, "A closer look at the relationship between academic achievement and language proficiency among Iranian EFL students," Theory and Practice in Language Studies, vol. 1, pp. 1740-1748, December 2011.

[12] L. L. Garnace, "Correlates of English performance among fourth year high school students in Philippine Science High School-Eastern Visayas Campus, Science and Technology streams," M.S. thesis, Leyte Normal University, Tacloban City, 2001.

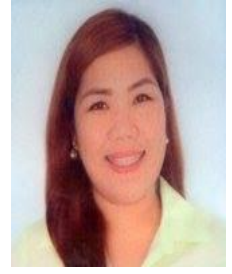

Robelle Millie Ann B. Racca is from Laoag City, Ilocos Norte, Philippines. She was born on January 23, 1989. She earned her master of arts degree in education majored in language and at the Mariano Marcos State University (MMSU) Graduate School, Laoag City, Philippines in 2016.

At present, she is a special science teacher 1 at the Philippine Science High School - Ilocos Region Campus located in San Ildefonso, Ilocos Sur.

Ms. Racca is a member of Alliance of Language and Literature Teachers, School Press Advisers Movement, Inc., and Linguistic Society of the Philippines.

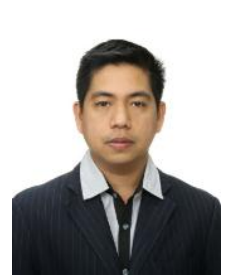

Ronald Candy S. Lasaten is from the City of Batac, Ilocos Norte, Philippines. He was born on January 16, 1981. He earned his doctor of philosophy degree in applied linguistics at the Mariano Marcos State University (MMSU) Graduate School, Laoag City, Philippines in 2012.

$\mathrm{He}$ is presently an English professor at the Mariano Marcos State University College of Teacher Education (CTE), Laoag City. He is the Program Adviser for English, College Coordinator for Instructional Materials Development, Coordinator for Board Licensure Examination for Professional Teachers (BLEPT) Review and the Head Editor of the CTE Research Journal. His papers titled "English Language Needs of Teachers at Bangplama Soongsumarnpadhungwit School, Suphanburi, Thailand," and "Analysis of Errors in the English Writings of Teacher Education Students," were published in the Researchers World: Journal of Arts Science and Commerce in 2014. He also wrote a book titled Literatures of the World: Teaching and Learning in the Constructivist Approach (Quezon City: IPM Publishing, Inc., 2011). His research interests include linguistics, language, literature, language and literature teaching, language and literature assessment, instructional materials development and integration of ICT in education.

Dr. Lasaten is a member of Linguistic Society of the Philippines (LSP), Inc., College English Teachers Association (CETA), Council of the Department Chairpersons for English (CDCE), Philippine Association for Teacher Education (PAFTE), Philippine Association for Language Teaching (PALT), Inc. and International English Learners Training Institute (IELTI). He was awarded the Outstanding Teacher of MMSU in 2014. 